\title{
ホロニック生産システムにおけるリアルタイム スケジューリングに関する研究*
}

（第 2 報，システム状態の予測に基づく効用値の決定）

\author{
岩 村 幸 治*1, 森下 大 $^{* 2}$ \\ 谷 水義 隆*1, 杉 村 延 広*1
}

\section{A Study on A Real-Time Scheduling of Holonic Manufacturing Systems (2nd Report, Determination of Effectiveness Values Based on Estimation of Future Status of HMS) \\ Koji IWAMURA*3, Yutaka MORISHITA, Yoshitaka TANIMIZU and Nobuhiro SUGIMURA \\ *3 Graduate School of Engineering, Osaka Prefecture University, 11 Gakuen cho, Sakai shi, Osaka, 599-8531 Japan}

\begin{abstract}
This paper deals with a real time scheduling system of HMS (Holonic Manufacturing System). A decision making process based on the effectiveness values have been proposed and applied to the real-time scheduling problems of the HMS in the previous report. New systematic methods for the individual holons are proposed, in the paper, to determine the effectiveness values based on the estimation of the future HMS status, aiming at improving the previous methods. Simulation based procedures are newly developed and implemented to estimate the future HMS status and to determine the effectiveness values. The effectiveness of the proposed methods are verified through the case studies.
\end{abstract}

Key Words: Holonic Manufacturing System, Decision Making Procedure, Real-Time Scheduling, Estimation of Future Status, Simulation

\section{1. 粕言}

生産システムの構成要素が通信機能と意思決定機 能を持ち，情報交換を行いながら自律的に生産プロセ スを実行する自律分散型生産システム(1)の概念が提 案されている. その中のひとつにホロニック生産シス テム (Holonic Manufacturing System) (5)がある. 以下 では，これをHMS と呼ぶ。

著者らは，HMS のリアルタイムスケジューリング 手法について研究を行ってきている. これまでの研究 9・11では，効用值に基づくホロンの意思決定プロセス を提案し，効用値を用いてリアルタイムスケジューリ ングを行うことで，ヒューリスティックルールを用い た従来のスケジューリング手法よりも, 各ホロンの目 的関数の值が全体として良くなることを示した. しか し，この手法では，各ホロンは次工程のみを考虑して 効用值を決定しており，HMS の将来の状態を考えた 時, 必ずしも適切な効用值を求めているとは言えない． そこで本研究では, 各ホロンが HMS の将来の状態

* 原稿受付 2004 年. 4 月 8 日.

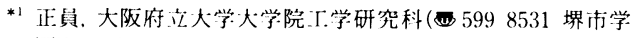
園町 1 1).

*2 学生員, 大阮府话大学大学院目学研究科。

E mail : iwamura (a mecha.osakafu u.ac.jp
を予測して効用值の決定を行う手法について検討する. 本論文では，その第一段階として，ホロンが HMS の 状態を正確に予測することができる場合について，予 測に基づく効用值の決定方法を提案する.

自律分散型の生産システムにおける予測に基づく スケジューリングに関する研究として, 山本は生産シ ステム全体の稼㗢率を予測し，この予測を基に AGV の行動をリアルタイムに決定する手法を提案している (12) (13). また, これにより, 生産システム全体におけ る各部品の目標生産比率を遵守する搬送スケジュール を実現している.これに対して，本研究は，機械加工 プロセスを対象とし, 各ホロンの目的関数の值を改善 することを目的とする.

\section{2 予測に基づくホロンの意思決定プロセス}

前報(9)では，ある時刻 $\mathrm{t}$ において加工プロセスが終 了したホロンおよび待機状態にあるホロンが，次の加 エプロセスのスケジュールを効用值に基づいて決定す る手法を提案した，本論文では，HMS の状態の予測 に基づいて効用值を求めるために, 図 1 に示寸ように, 以下の 5 つのプロセスからなる手順を提案する. この うち，(3)が新たに予測のために追加するプロセスであ る. 
（1）各ホロンの状態の収集 : 各ホロンは, 時刻 $\mathrm{t}$ にお ける他のホロンの状態に関する情報を収集する. 寸な わち, ジョブホロンは各リソースホロンが加工可能な 加工プロセスを, リソースホロンは各ジョブホロンの まだ実行されていない加工プロセスを求める.

(2) 候補ホロンの選択 : 各ホロンは, 次の加工プロセ スを実行するために候補となるホロンを求める. 寸な わち, ジョブホロンは, 次の加工プロセスを加工する ことができるリソースホロンを求める. リソースホロ ンは, まだ実行されていない加工プロセスの中で実行 することができる加工プロセスを求め, その加工プロ セスを持つジョブホロンを候補とする.

(3) HMS の状態の予測 : 各ホロンは, 候補ホロンに ある効用值を与えた場合について, HMS の将来の状 態を予測する.この予測は, HMS のシミュレーショ ンにより行う。この予測プロセスの詳細については, 第3節に示寸.

(4) 効用値の決定 : 各ホロンは, (3)で予測した HMS の状態の内, 自身の目的関数の值が最も良くなった HMS の状態に基づいて, 候補ホロンの効用值を決定 する. 効用值は 0 から 1 の範用で与え, 目的関数を良 くするために最も適する候補ホロンに, 効用値 1 を与 える.

(5) 協調 : 各ホロンは, 候補ホロンの効用值をコーデ イネーションホロンに送る. コーディネーションホロ ンは, 各ホロンからの効用值に基づいて, 次の加工プ ロセスを実行するためのリソースホロンとジョブホロ ンの組み合わせを決定する. この時, コーディネーシ ヨンホロンは, 効用值の和が最大となるリソースホロ ンとジョブホロンの組み合わせを求める.

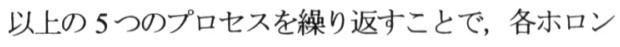
は次に実行する加工プロセスを決定する.

\section{HMS の状態の予測}

\section{$3 \cdot 1$ 予測を行うための前提条件 本研究では,}

HMS の構成要素であるリソースホロン, ジョブホロ ンおよびコーディネーションホロンの意思決定行動に ついてミュレーションを行うことで, HMS の状態 を予測する方法を考える. HMS において各ホロンは 自身の意思決定基淮に基づいて行動する. ジョブホロ ンとリソースホロンの意思決定基淮は効用值の算出の 方法であり，コーディネーションホロンの意思決定基 準は協調の方法である.

本論文では，予測に基づく効用值の有效性を检証 することを目的として，ホロンが HMS の状態を正確

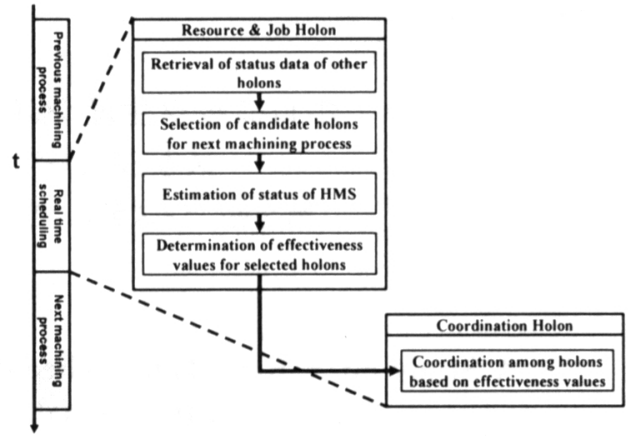

Fig. 1 Real-time scheduling processes based on estimation of status

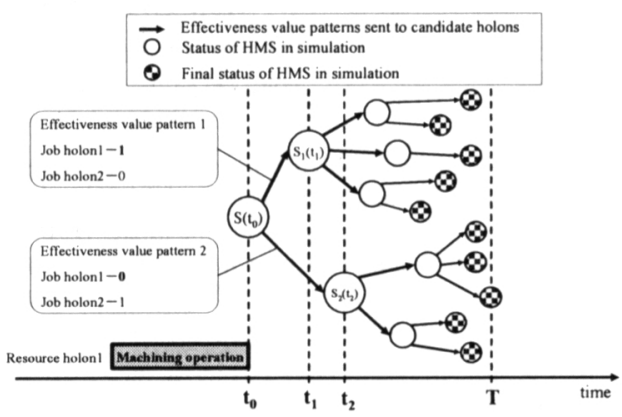

Fig. 2Estimation of status of HMS by simulation

に予測することができる場合を考える，そのために， 以下の仮定をおくことにより，問題を簡単化する.

(1) HMSにおいて予測を行うホロンは一つである.

（2）他のホロンの意思決定基淮を既知として予測する.

3.2 HMS の状態の予測 ホロンがシミュレーシ ヨンを行うことにより, HMS の状態を予測する方法 を図 2 に示寸. ホロンは, 次の加工プロセスの候補ホ ロンにある効用值を与えた場合に HMS の状態がどの ように変化するかを, シミュレーションを行うことに より予測する. シミュレーションにおける HMS の状 態変化を次のように定義する.

$$
\mathrm{S}(\mathrm{t})=\left(\mathrm{h}_{1}(\mathrm{t}), \mathrm{h}_{2}(\mathrm{t}), \cdots, \mathrm{h}_{\mathrm{k}}(\mathrm{t})\right)
$$

ここで, $h_{1}(t), h_{2}(t), \cdots, h_{k}(t)$ は, シミュレーションに おいて, HMSに含まれるすべてのホロンの時刻 $\mathrm{t}$ にお ける状態を表す, h(t)はホロン i について, 以下の情 報を含む.

（1）待機中であるか加工中であるかの情報.

（2）待機中の場合は待機が終了する予定時刻, 加工中 の場合は現在の加工プロセスが終了する予定時刻.

(3)これまでに実行した加工プロセスの情報.

(4) 目的関数の值. 
シミュレーションの実行手順を以下に示す.この とき, シミュレーションの開始時刻を $\mathrm{t}_{0}$ とする. また, シミュレーションを行うホロンを, 以下では当該ホロ ンと呼ぶ.

STEP1 : 効用值のパターンの生成

時刻 $\mathrm{t}_{0}$ における HMS $の$ 状態 $\mathrm{S}\left(\mathrm{t}_{0}\right)$ を初期状態として, 当該ホロンの次の加工プロセスを実行する際の候補ホ ロンを求め, 各候補ホロンの効用値の組合せを生成す る. この時, 複数の候補ホロンに対してどのような効 用值を与えるかについては, 複数の組合せを考えるこ とができる，ここでは，候補ホロンに与える効用值の 組合せを効用值のパターンと呼ぶ。効用值のパターン の数を制限するために, 候補ホロンが一つの場合は効 用值 1 を, 複数の場合はその内の一つに効用值 1 を与 え，その他の候補ホロンに対しては効用值 0 を与える こととする. すなわち, 図 2 に示すように, 時刻 $\mathrm{t}_{0}$ に おいては $\mathrm{n}$ 個の候補ホロンに対して, $\mathrm{n}$ 通りの効用值 のパターンを生成する.

STEP2 : 次の意思決定を行なう時刻 $\mathrm{t}_{\alpha}(\alpha=1,2, \cdots)$ までのシミュレーション

STEP1 で生成した効用值のパターンについて, 当 該ホロンは次の意思決定が必要となる時刻 $\mathrm{t}_{\alpha}$ までシ ミュレーションを行い, $\mathrm{t}_{\alpha}$ における HMS の状態 $\mathrm{S}_{\alpha}\left(\mathrm{t}_{\alpha}\right)$ を求める. この際, 当該ホロン以外のホロンの 意思決定基淮は既知であるため, 一つの効用值のパタ ーンに対して, 一つの状態が得られる.この結果, 図 2 に示すように, $\mathrm{t}_{0}$ の状態から $\mathrm{n}$ 個の状態 $\mathrm{S}_{\alpha}\left(\mathrm{t}_{\alpha}\right)$ が生成 される.

STEP3 : 終了時刻 T までのシミュレーション

STEP2 で得られたすべての状態を初期状態として, STEP1 および STEP2を繰り返すことにより, 図 2 に示 すように, 当該ホロンが意思決定を行なう時刻 $\left(\mathrm{t}_{0}, \mathrm{t}_{\mathrm{l}}\right.$, …ににおいて HMS の状態が分岐しながら，あらかじめ 決められたシミュレーションの終了時刻 T における HMS の状態を得ることができる. すなわち, シミュ レーションの結果として, 当該ホロンは時刻 $\mathrm{t}_{0}$ から $\mathrm{T}$ までにおける HMS のすべての可能な状態と効用值の パターンを得る.

$3 \cdot 3$ シミュレーションの終了時刻 図 2 に示す シミュレーションでは, 終了時刻 $\mathrm{T}$ の設定が重要とな る. 終了時刻 T を大きくすると HMS の状態の予測を 長期間行うことにより適切な効用值を求めることがで きるが, 計算時間が増大する. そのため, 本研究では 以下の 3 種類の終了時刻を考える.

(1) すべての生産プロセスの終了時刻 : $T_{1}$

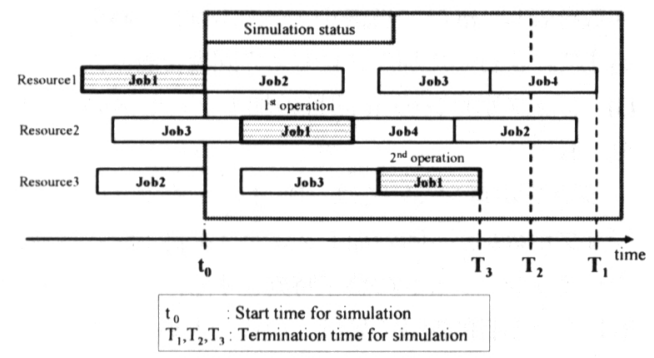

Fig. 3Termination time for simulation

Table 1 Objectives and Objective functions of holons

\begin{tabular}{|c|c|l|}
\hline \multicolumn{2}{|c|}{ Objectives } & \multicolumn{1}{c|}{ Objective functions } \\
\hline \multirow{2}{*}{$\begin{array}{c}\text { Resource } \\
\text { Holon }\end{array}$} & Efficiency & $\Sigma$ Machining Time/Total Time \\
\cline { 2 - 3 } & $\begin{array}{c}\text { Machining } \\
\text { Accuracy }\end{array}$ & $\begin{array}{c}\Sigma \text { (Machining Accuracy of Resources- } \\
\text { Required Machining Accuracy of Jobs) }\end{array}$ \\
\hline \multirow{2}{*}{$\begin{array}{c}\text { Job } \\
\text { Holon }\end{array}$} & $\begin{array}{c}\text { Total Processing } \\
\text { Time }\end{array}$ & $\Sigma$ (Machining Time+ Waiting Time) \\
\cline { 2 - 3 } & MachiningCost & $\Sigma$ (Machining Cost of Resources) \\
\hline
\end{tabular}

図 3 に示すように, すべての生産プロセスが終了 する時刻 $\mathrm{T}_{1}$ までシミュレーションを行う。この場合, ジョブホロン, リソースホロンのそれぞれにおいて, 候補ホロンにある効用值を与えた場合の, 時刻 $\mathrm{T}_{1}$ に おける目的関数の值を, 前報(9)で提案した表 1 に示す 目的関数により求めることができる. 表 1 において, 各目的関数におけるミは，生産プロセスが開始してか ら，すべての生産プロセスが終了する時刻までに，ホ ロンが実行した加工プロセスの回数に対して和をとる ことを意味する.

シミュレーションの終了時刻を $\mathrm{T}_{1}$ とする場合, 計 算の負荷が大きくなるという問題がある.このため,

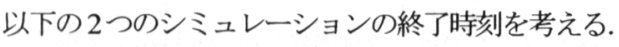

(2) $\mathrm{t}_{0}$ から $\mathrm{T}_{1}$ の間の終了時刻: $\mathrm{T}_{2}$

リソースホロンについては, 図 3 に示すように, $\mathrm{t}_{0}$ から $\mathrm{T}_{1}$ の間の時刻 $\mathrm{T}_{2}$ をシミュレーションの終了時刻 とする. この時, 時刻 $\mathrm{T}_{2}$ における目的関数の值は, 次式で求めることができる.

- 稼働率

$\stackrel{1+m}{\sum}$ Machining Time $/ \mathrm{T}_{2}$

- 加工精度

$\Sigma^{1+m}$ (Machining Accuracy of Resources-

Required Machining Accuracy of Jobs) *.

ここで，1は，当該リソースホロンがシミュレーシ ヨンを開始する時刻 $\mathrm{t}_{0}$ までに実行した加工プロセスの 
回数を表し, $\mathrm{m}$ は, 当該リソースホロンが時刻 $\mathrm{t}_{0}$ から $\mathrm{T}_{2}$ までに実行した加工プロセスの回数を表す.

(3) ジョブホロンの $\mathrm{n}$ 回目の加工プロセスの終了時 刻: $\mathrm{T}_{3}$

ジョブホロンついて, 図 3 に示すように, 当該 ジョブホロンが n回の加工プロセスを終了する時刻 $\mathrm{T}_{3}$ をシミュレーションの終了時刻とする. この時，時刻 $\mathrm{T}_{3}$ における目的関数の值は, 次式で求めることができ る.

- 加工時間

$\sum^{1+n}$ (Machining Time + Waiting Time)

- 加工コスト

$\sum^{1+n}$ (Machining Cost of Resources)

ここで, 1 は, 当該ジョブホロンが, シミュレーシ ヨンを開始する時刻 $\mathrm{t}_{0}$ までに実行した加工プロセスの 回数を表す.

34 効用値の決定 シミュレーションの実行結 果に基づいて，当該ホロンが，候補ホロンの効用值を 決定する方法を説明する. 当該ホロンは, シミュレー ションを実行した結果，以下の情報を得る.

(1) シミュレーションの終了時刻 T における, HMS のすべての可能な状態 $\mathrm{S}_{\mathrm{i}}(\mathrm{T})(\mathrm{i}=1,2, \cdots, \mathrm{p})$.

(2) 各 HMS の状態 S $(T)$ から得られる, 当該ホロンの 目的関数 $\sigma$ 值 $O F V_{\mathrm{i}}$.

(3) すべての実行可能な効用值のパターンの順序.

最も目的関数の值を良くする HMS $の$ 状態 S(T) of Imax $_{\text {max }}$ は, 以下の式により与えられる.

$$
S(T)_{\text {OFVmax }}=S_{i}(T): O_{i} \geqq \mathrm{OFV}_{j}(i \neq j)
$$

以上のことから, 当該ホロンは, $S(T)_{\text {b F Vmax }}$ を得るた めに時刻 $\mathrm{t}_{0}$ に候補ホロンに与えた効用值を，コーディ ネーションホロンに送る効用值とする.

\section{4. ケーススタディ}

本論文で提案する手法の有効性を検証するために, リアルタイムスケジューリングのケーススタディを行 った. 対象とする HMS の構成は前報(9)と同一である. すなわち, 10 台のマシニングセンタ（リソースホロ ン）を用いて 12 個の製品（ジョブホロン）が生産さ れるケースを考える. ケーススタディの条件としては, 以下の組み合わせを考える.

(1) ジョブホロンの加工工程 : 2 通り(Casel, 2)

(2) リソースホロンの目的関数 : 2 通り(CaseA，B)

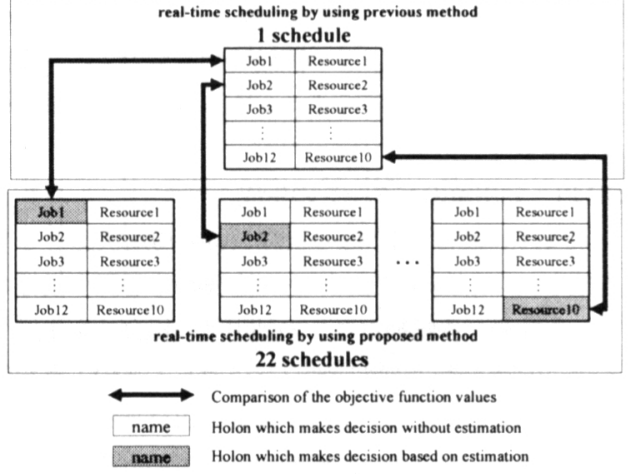

Fig. 4 Case study

（3）リソースホロンの加工時間, 加工精度, 加工コス トの組み合わせ : 3 通り(Case (1)，(2)，(3)

これらの組み合わせにより，12 通りの条件を設定 することができる. なお, ジョブホロンには, 加工工 程数 (ジョプの生産に必要な加工プロセスの総数) が 4工程のものと6工程のものを作成している.

予測を用いる意思決定プロセスの有效性を検証す るために, 図4 に示す手順でケーススタディを行う. まず，比較の対象として，すべてのホロンが予測を行 わない従来の意思決定プロセスを実行してリアルタイ ムスケジューリングを行う. 次に, 10 個のリソース ホロンおよび, 12 個のジョブホロンのそれぞれにつ いて, 一つのホロンが予測に基づく意思決定プロセス を実行し, 他のホロンが従来の意思決定プロセスを実 行して, リアルタイムスケジューリングを行う。これ により一つの条件について 22 個のスケジュールが得 られる. このスケジュールに基づいて, 各ホロンの目 的関数の值が, 予測を用いた場合にどの程度改善され るかを検討する.

はじめに，予測を用いるホロンが，すべての生産 プロセスが終了する時刻 $\mathrm{T}_{1}$ までシミュレーションを 行う場合について考える.

スケジューリングの結果の一例を, 図 5(a)およぴ b) に,ガントチャートの形で示寸. 同図(a)はすべてのホ ロンが従来の意思決定プロセスを実行することにより スケジューリングを行った結果を示し, 同図(b)は Job5 のみが予測を用いた意思決定プロセスを実行してスケ ジューリングを行った結果を示寸。Job5が予測を用い た意思決定プロセスを実行することで, 自身の加工プ ロセスを終了するまでの時間を短縮できていることが わかる.

図 6 に 12 の条件のケーススタディに対して比較を 行った結果を示寸. 図6の横軸は各ホロンの目的関数 
を，縦軸は予測を用いることにより目的関数の值が改 善したホロンの数を示す. 図 6 より, すべての目的関 数において, 予測を用いることにより, 各ホロンが目 的関数の值を改善している事がわかる.

つぎに, シミュレーションの終了時刻と予測の効 果との関係を検討する. そのために, リソースホロン については, あらかじめ定められた時刻 $\mathrm{T}_{2}$ まで, ジ ヨブホロンについては, ある回数の加工プロセスを終 了する時刻 $\mathrm{T}_{3}$ までシミュレーションを行う.

すべての加工プロセスが終了する時刻 $T_{1}$ まで予測 する場合を基準とし， $\mathrm{T}_{2}$ もしくは $\mathrm{T}_{3}$ まで予測する場 合の目的関数の值を達成率と呼ぶ，達成率は，リソー スホロンおよびジョブホロンに対して，以下のように なる.

(1) リソースホロンの稼働率の達成率

$$
\mathrm{X}=\mathrm{OFV}_{\mathrm{T}_{2}} / \mathrm{OFV}_{\mathrm{T}_{1}}
$$

（2）リソースホロンの加工精度の達成率

$$
\mathrm{X}=\mathrm{OFV}_{\mathrm{T}_{1}} / \mathrm{OFV}_{\mathrm{T}_{2}}
$$

(3) ジョブホロンの加工時間, 加工コストの達成率

$$
\mathrm{X}=\mathrm{OFV}_{\mathrm{T}_{1}} / \mathrm{OFV}_{\mathrm{T}_{3}}
$$

ここで, $\mathrm{OFV}_{\mathrm{T}}$ は，T まで予測を行った場合の目的 関数の值を示寸，また，式(8)および(9)の達成率は，值 が小さいほど目的関数は良好になるため, 分母が $\mathrm{T}_{2}$ もしくは $\mathrm{T}_{3}$ まで予測する場合の值としている. さら に, 各ホロンの達成率の平均を, 平均達成率 $\mathrm{Y}$ と呼 び, 次式で定める.

$$
\mathrm{Y}=\sum_{\mathrm{i}=1}^{\mathrm{N}} \mathrm{X}_{\mathrm{i}} / \mathrm{N}
$$

ここで， $\mathrm{X}_{\mathrm{i}}$ はホロン $\mathrm{i}$ の達成率， $\mathrm{N}$ はホロンの総数 である. リソースホロンについて, シミュレーション による予測の終了時刻 $\mathrm{T}_{2}$ と達成率との関係をまとめ ると図 7 のようになる. 図中の横軸 $\mathrm{t}$ は, ジョブホロ ンの各加工工程における加工時間の平均值である. シ ミュレーションによる予測を終了する時刻は, この $\mathrm{t}$ を基淮にして 0 から $7 \mathrm{t}$ まで変化させている. また, すべての加工プロセスの終了時刻は, 生成されるスケ ジュールにより異なり, 今回のケーススタディにおけ る加工プロセスの終了時刻は， $8 \mathrm{t}$ から $10 \mathrm{t}$ の範井にな っている. 図7(a)および(b)は，それぞれ目的関数が 稼働率およひ加工精度の場合の達成率を示している. いずれの場合についても，予測する時間を長くすると 達成率は増加している。 また, 達成率が 95\%となる予

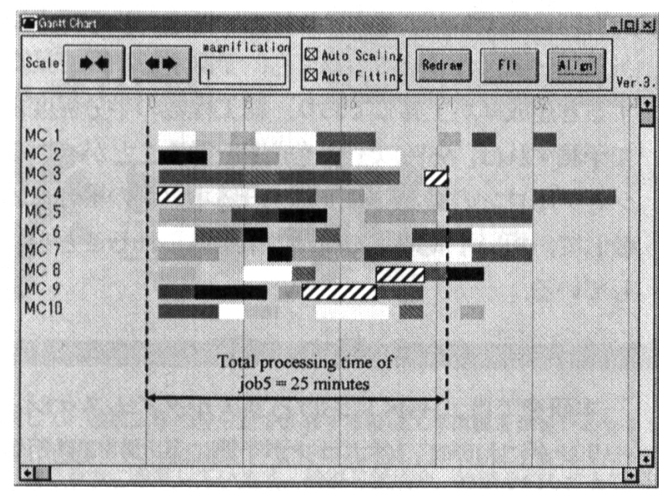

(a) Previous method

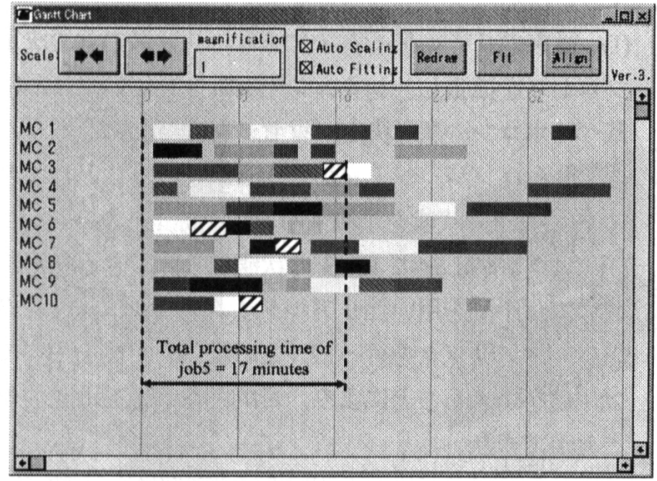

(b) New method based on estimation

Fig. 5 Gantt chart of scheduling results

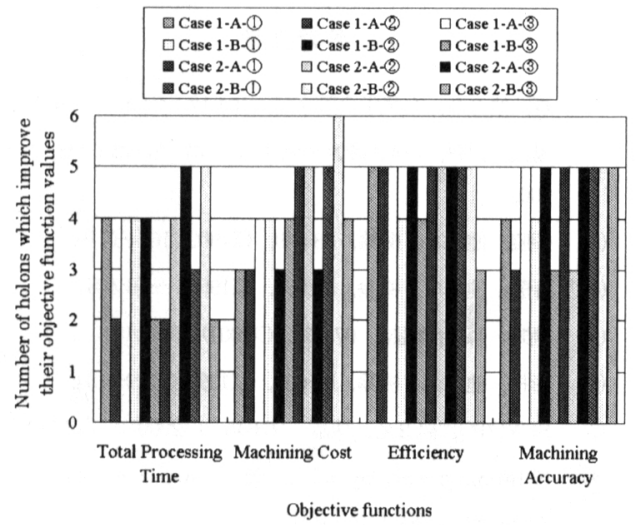

Fig. 6 Results of case study

測期間は, $7 \mathrm{t}$ から $8 \mathrm{t}$ となっている。 すなわち, リソ 一スホロンの場合には, シミュレーションをほぼす心 ての加工プロセスが終了する時刻まで行わないと, 高 い予測の効果が得られないことを示している.

図 8 は, ジョブホロンの達成率をまとめたものであ る. 同図(a)および(b)は，それぞれ加工工程数が 4 工程 
および 6 工程のジョブホロンについてまとめたもので ある.いずれの場合についても，予測する期間を長く すると達成率が上昇しており, 総工程数の半分程度ま で予測すれば，95\%以上の達成率を得ることができる. ジョブホロンの場合には, リソースホロンの場合と比 較して，短い予測期間で高い効果が得られることを示 している.

\section{5. 結言}

本研究では, HMS におけるリアルタイムスケジュ ーリングにおいて, 各ホロンが予測に基づいて効用値 を決定する手法を提案した. 内容をまとめると以下の ようになる.

(1) 従来のリアルタイムスケジューリングの意思決定 プロセスを拡張し, シミュレーションを用いた予測に 基づくホロンの意思決定プロセスを提案した.

(2) 各ホロンが, シミュレーションを行うことにより， HMS の将来の状態を予測する方法を提案した.

(3) ホロンが正確に HMS の状態を予測できる状況に おいて，予測を用いたリアルタイムスケジューリング のケーススタディを行った. この結果, 予測を用いて 効用值を求めることにより, 目的関数の值を改善する ことができた.

(4) シミュレーションを用いた予測期間が, 各ホロン の目的関数に与える影響を検討し, 予測期間を長くす ると, 目的関数の值が改善されることを示した.

\section{参考文献}

（1）森, 他 2 名, 電気学会論文誌, 104-12, C (1984), 303-311.

（2）湯浅・伊藤，計測自動制御学会論文集，25-12(1989)，93100.

（3）森脇，他 3 名，機論，58-549， $(1992), 1674-1679$.

（4）森脇，他 4名，機論，59-568，O(1993), 3976-3981.

（5）樋野・森脇，機論，67-658，C(2001), 2063-2069.

(6) 杉村, 他 2名, 機論, 65-633, O(1999), 21292134.

(7) SUYOTO, 他 2 名, 機論, 66-645, C(2000), 1718-1723.

(8) K. Iwamura et.al, Japan-USA Symposium on Flexible Automation (2002), 967-970.

（9）岩村, 他 2 名，機論， 69-682， O(2003), 1733-1738.

(10) K Iwamura et. al., 7th World Multiconference on Systemics, Cybernetics and Informatics (2003), Vol 8, 261-266.

(11) K Iwamura et. al, 5th International Conference on Design of International Infrastructure Systems for Manufacturing, (2002), 3-14.

(12) 山本, 機論, 65-631, O(1999), 1281-1287.

(13) 山本, 機論, 66-644, O(2000), 1388-1393.

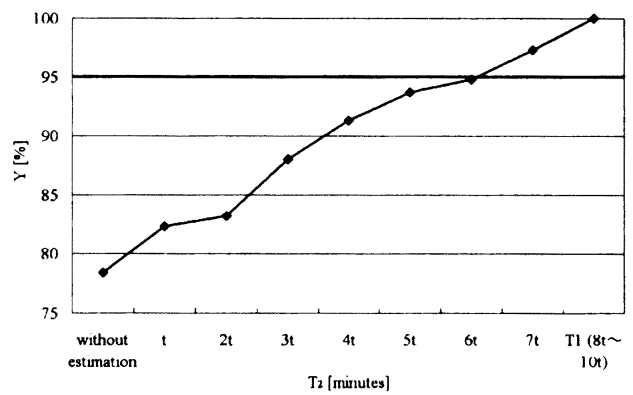

(a) Efficiency

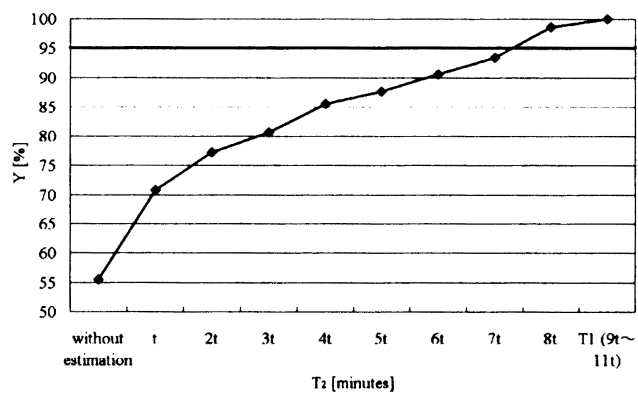

(b) Machining aocuracy

Fig. 7 Effects of simulation time (Resource holon)

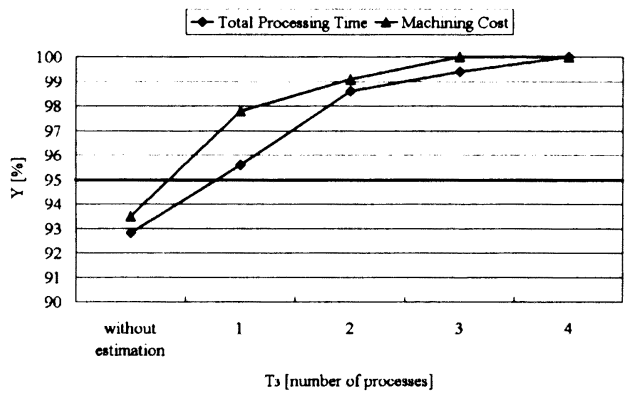

(a) Job holons with 4 machining proceses

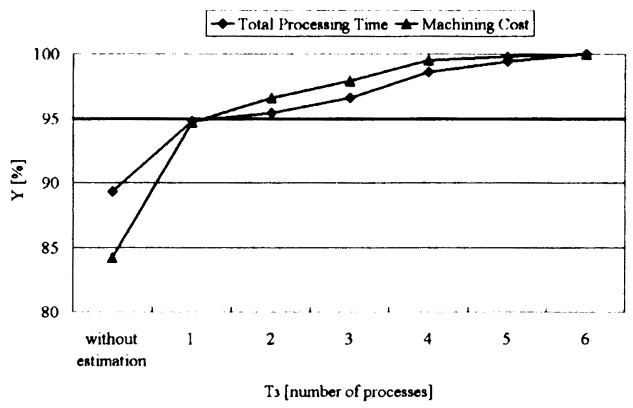

(b) Job holons with 6 machining prooseses

Fig. 8 Effects of simulation time (Job holon) 